\title{
PELAYANAN HAMBA TUHAN DALAM TUGAS PENGGEMBALAAN
}

\author{
JEMAAT \\ Oleh: Joko Santoso ${ }^{1}$ \\ peltu_jojosan@ymail.com
}

\begin{abstract}
The Servant of God in the pastoral care of the congregation in the millennial era was subjected to severe testing and challenges. The influence of the progress and development of civilization greatly impacts and erodes the truth values that have been instilled by church fathers. Purity as a servant of God in carrying out the ministry of pastoral care is at stake. Loyalty to the Bible as a source of behavior and the carrying out of church service calls is questionable. And service as a servant of God has been a struggle in life throughout church history. This study aims to find the extent to which there has been a shift in the value of God's servants in carrying out their ministry. The result is a clear illustration of how important it is as a servant of God to remain consistent in keeping with the Bible, the source of behavior and measuring tools for the life of God's servants as a form of accountability for carrying out the ministry of pastoral care to God.
\end{abstract}

Keywords: God's Servant, Purity, Pastoral Service.

\begin{abstract}
Abstrak
Pelayanan Hamba Tuhan dalam tugas penggembalaan jemaat di era mileniel mendapat ujian dan tantangan berat. Pengaruh kemajuan dan perkembangan peradaban sangat berdampak dan mengikis nilai-nilai kebenaran yang telah ditanamkan oleh bapa-bapa gereja. Kemurnian sebagai hamba Tuhan dalam melaksanakan tugas pelayanan penggembalaan jemaat dipertaruhkan. Kesetiaan terhadap Alkitab sebagai sumber perilaku dan pelaksanaan panggilan pelayanan jemaat dipertanyakan. Dan pengabdian sebagai hamba Tuhan menjadi pergumulan hidup dalam sepanjang sejarah gereja. Penelitian ini bertujuan menemukan sejauh mana telah terjadi pergeseran nilai hamba Tuhan dalam melaksanakan tugas pelayanan. Hasilnya menjadi gambaran nyata betapa pentingnya sebagai hamba Tuhan tetap konsisten menjaga diri sesuai dengan Alkitab sumber perilaku dan alat ukur kehidupan hamba Tuhan sebagai wujud pertanggung jawab pelaksanaan tugas pelayanan penggembalaan kepada Tuhan.
\end{abstract}

Kata kunci: Hamba Tuhan, Kemurnian, Tugas Pelayanan Penggembalaan.

\footnotetext{
${ }^{1}$ Joko Santoso adalah Selaku Wakil Ketua IV di Sekolah Tinggi Theologia Nazarene Indonesia dan dosen pasca sarjana S2 Teologi.
} 


\section{Pendahuluan}

Pada hakekatnya pelayanan tidak dapat dipisahkan dari kehidupan hamba Tuhan, sebagaimana yang telah ditunjukkan dan diprkatekkan dalam seluruh kehidupan Tuhan Yesus selama berada dibumi ini. Tuhan mengajarkan dan memberi teladan bagaimana hamba Tuhan harus hidup dan mengambil bagian dalam pelayan pekerjaan Tuhan (Matius 20:28; Lukas 19: 10). Begitulah bagi setiap hamaba Tuhan, ketika menyerahkan diri dan mendedikasikan diri sebagai pelayan Tuhan Yesus Kristus. Mengikuti apa yang diajarkan dan di perintahkanNya, yaitu menjadi berkat, melayani dan bersaksi bagi orang lain adalah harga mati (Matius 28:18-20; Kisah Para Rasul 2:8). Hal ini dapat diwujudkan jika setiap hamba Tuhan dapat menjaga diri dalam melaksankan tugas penggembalaan jemaat, dengan meretika yang benar dan sesuai dengan nilai nilai moral dan etika yang tertulis dalam Alkitab sumber hidup.

\section{Metodologi}

Penelitian ini menggunakan metode deskriptif kualitatif. Penelitian yang mendalam mengenai unit sosial tertentu, yang hasil penelitian itu memberi gambaran luas dan mendalam mengenai unit sosial tertentu. Rancangan penelitian kualitatif dengan cara penelusuran studi pustaka dan metode study Blibika dengan melakukan penelaah ayat-ayat yang terdapat dalam Alkitab. Sebagaimana Bambang Subagyo menjelaskan sebagai berikut: "Metode yang mengatur ajaran sebuah Kitab sesuai dengan doktrin-doktrin yang dibicarakan dan menjelaskan tekanan spiritual. ${ }^{22}$ Selanjutnya, peneliti membuat anggapan-anggapan dasar penelitian, mengklasifikasi kan ayat atau teks Alkitab ke dalam topik-topik tertentu sesuai dengan tema utama penelitian. Metode ini mencakup pengumpulan semua teks Alkitab yang sesuai dengan tema penelitian,

\footnotetext{
${ }^{2}$ Andreas B. Subagyo, Pengantar Riset Kuantitatif Dan Kualitatif, (Bandung: Yayasan Kalam Hidup),
} 2004, hal. 142. 
mengelompokkan frase ke dalam topik tertentu, menjelaskan frase tersebut, dan akhirnya menarik kesimpulan.

\section{Latar Belakang}

Kepemimpinan pada saat ini sedang mengalami masa yang kelam. Untuk menemukan pemimpin yang memiliki dedikasi yang tinggi sangat dibutuhkan. Berkenan dengan kepribadian pemimpin tentang integritas moral, kehormatan, nilai-nilai, teladan, dan standar yang layak dihormati selalu menjadi topik pembicaraan hingga kini. Myles Munroe dalam bukunya The Spirit Leadership, percaya bahwa krisis kepemimpinan terjadi karena kepemimpinan lebih dimaknai sebagai tindakan bukan panggilan. ${ }^{3}$ Sedangkan Walker Percy, dalam bukunya; The Thanatos Syndrome, mengatakan bahwa: "Zaman ini bukanlah zaman pencerahan, melainkan zaman ketidaktahuan tentang apa yang harus dilakukan." Para politikus, ilmuwan, doker, pembisnis, warga negara biasa, dan pelayan (minister) makin sadar bahwa mereka sedang dalam situasi di mana mereka tidak tahu harus berbuat apa. ${ }^{4}$

Menyingkapi hal tersebut diatas, sebagai hamba Tuhan khususnya, perlu dan harus membangun kesadaran tentang pemahaman keadaan zaman yang terjadi sekarang ini. Zaman yang kehilangan nilai-nilai etika, dimana setiap orang dapat menentukan keinginannya sendiri untuk melakukan apapapun walaupun melanggar norma dan etika, bahkan melanggar hukum yang berlaku didalam masyarakat dan kebenaran Alkitab sumber peraturan hidup. Hal ini sesungguhnya sudah pernah terjadi pada zaman hakim-hakim, dimana setiap orang bisa mengemukakan pendapatnya, lepas dari benar atau salah. Tetapi pendapat tersebut dapat menjadi prilaku atau konsep hidup yang dipakai oleh banyak orang. (Hakim-Hakim 21:25; 2 Timotius

3 http://kepemimpinanmelayani.blogspot.com/2016/12/materi-kuliah-kepemimpinan-kristen.html, diakses tanggal 9 Desember 2019, pukul 10.30 WIB.

${ }^{4}$ https://en.m.wikipedia.org/wiki/The Thanatos_Syndrome, diakses tanggal 9 Desember 2019 , pukul 10.40 WIB. 
3:1-9). Hamba Tuhan sebagai pelayan penggembalaan jemaat mengkhususkan diri menjadi pelayan gereja dengan keunikan peran moral dan tanggung jawab etis. Para pelayan gereja baik yang baru maupun yang sudah berpengalaman, tentang kewajiban-kewajiban etis yang patut dilakukan di zaman sekarang melalui kehidupan pribadi maupun kehidupan profesionalitas.

\section{Pembahasan}

Sebagai hamba Tuhan perlu memahami dan mengerti nilai-nilai kebenaran yang mengatur perilaku beretika terlebih dahulu sebelum melangkah lebih jauh. Hamba Tuhan harus mengetahui apa yang seharusnya melayani dalam penggembalaan jemaat. Memiliki pemahaman secara benar, sesuai dan tepat, serta mempraktekkannya dengan baik dan berhasil, sehingga dapat mencapai tujuan. Hamba Tuhan harus memahami bahwa hakekat hamaba Tuhan adalah melayani. Hamba Tuhan harus memahami konsep melayani yang seperti apa yang seharusnya hamba Tuhan lakukan. Hamba Tuhan harus memahami bagaimana hamba beretika dan berperilaku yang benar, sehingga membawa dampak besar pada pelayanan penggebalaan jemaat.

\section{Pemahaman Kemurnian Pelayanan Hamba Tuhan}

\section{Pengertian Pelayanan Dalam Alkitab}

Pelayanan dari kata benda "pelayan” yang memiliki arti “orang yang melayani” berubah menjadi kata kerja "melayani" yang berkaitan dengan pekerjaan dan berubah lagi menjadi "pelayanan". Lebih lanjut untuk memahami arti pelayanan dapat disimpulkan suatu kegiatan

yang dilakukan oleh seseorang atau sekumpulan orang untuk memenuhi kebutuhan orang lain. Jadi, pelayanan berarti seseorang yang melakukan suatu pekerjaan pelayanan yang dilakukan untuk orang lain. Sebagai pelayan seorang hamba Tuhan memposisikan diri sebagai hamba yang 
melayani Tuhan tuannya. Sebagaimana Yesus ajarkan, bahwa Dia menempatkan diri sebagai pelayan dan dipanggil bukan untuk dilayani tetapi untuk melayani (Lukas 22:27; Matius 20:28).

Ada beberapa kata pelayan yang di pakai di Perjanjian Baru yang di terjemahkan sebagai pelayan: "doulos" diartikan hamba; dan "diakonos" diartikan pelayan, penjaga atau pendeta. ${ }^{5}$

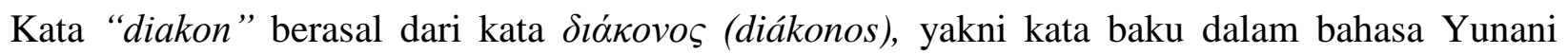
Kuno yang berarti "pelayan”, “penunggu”, “pemangku”, atau "pewarta". ${ }^{6}$ Paulus seorang rasul tetapi tidak merasa malu menyatakan dirinya sebagai hamba Yesus Kristus (Roma 1:1; 2 Korintus 4:5; Galatia 1:10; Filipi 1:1; Titus 1:1). Rasul Paulus kerapkali menyatakan dirinya sebagai pelayan Yesus Kristus (1 Korintus 3:5; 2 Korintus 3:6; 6:4; Efesus 3:7; Kolose 1:23). Disini rasul Paulus tidak memberikan pembedaan antara pelayan Allah dengan pelayan Umat Allah (2 Korintus 4:5).

Dalam perkembangan penggunaan kata pelayanan menunjuk pada program-porgram gereja yang dilakukan baik untuk kedalam anggota jemaat sendiri maupun kepada orang di luar anggota jemaat. Perkembangan sejarah gereja banyak jenis dan ragam pelayanan yang terus berkembang sesuai dengan kebutuhan gereja dan masyarakatnya maupun pergumulannya. Pelayanan menjadi ruang pengabdian yang diimplementasikan kepada amanat Tuhan Yesus Kristus yang diwujudkan kepada sesama manusia. Gerrit Singgih bahwa pelayanan "berarti mengubah orientasi, dari ingat diri sendiri (self interest, dengan pamrih) mengarahkan pada kepentingan orang lain."7

\footnotetext{
${ }^{5}$ https://alkitab.mobi/renungan/sh/2015/03/27/, diakses tanggal 9 Desember 2019, pukul 11.17 WIB.

${ }_{7}^{6}$ https://id.wikipedia.org/wiki/Diaken, diakses tanggal 9 Desember 2019, pukul 11.20 WIB.

7 http://pandiealfons.blogspot.co.id/melayani-bukan-dilayani-suatu-analisa.html, diakses tanggal 9 Desember 2019, pukul 11.24 WIB.
} 


\section{Pelayanan Penggembalaan Yang Alkitabiah}

Sering ada pernyataan yang mengatakan bahwa ada orang yang sudah melayani Tuhan dan bahkan telah menyerahkan dirinya sepenuhnya kepada Tuhan. tetapi yang sesungguhnya tidak melakukan kehendak Tuhan, melainkan melakukan kehendaknya sendiri. Mengatas namakan melayani Tuhan tetapi didalamnya adalah agenda pribadi. Tidak heran Tuhan memberi peringatan keras dalam Matius 7:21-23. Dengan tegas Yesus menegur dan bahkan menghardik orang-orang yang menyatakan diri telah bernubuat, mengusir setan dan menyembuhkan orang sakit, berarti sudah dikatakan melayani Tuhan. Apapun yang dilakukan oleh orang yang melayani Tuhan tetapi beroreintasi pada dirinya, buka melayani kehendak Tuhan tetapi melayani kehendaknya sendiri.

Rasul Paulus memberi contah tentang pengalamannya melayani Tuhan dalam Kisah Para Rasul 16:6-9, diceritakan bagaimana Paulus mencoba bahkan berusaha untuk melayani menurut apa yang ditetapkan hatinya, meski bukan untuk kepentingan dirinya. Tetapi didalam perjalanannya, pribadi Yesus dan Roh Kudus harus menghentikan perjalannya melalui berbagai musibah dan karam kapal untuk menghalangi tujuan pelayannya. Sampai akhirnya Tuhan memberikan penglihatan yang menyadarkannya, bahwa Tuhan menghendaki mengabarkan Injil ketempat lain. Seorang pelayan Tuhan dinyatakan benar-benar melayani Tuhan, jika apa yang dilakukannya berfokus pada kehendak Tuhan. walaupun sukar, penuh perjuangan dan penderitaan, bahkan mengalami banyak rintangan dan tantangan. Ratapan 3:49-58, merupakan jeritan dan keluh kesah Yeremia ketika berhadapan dengan tantangan yang berat dalam pelayanannya, tetapi tetap melakukan kehendak Tuhan dan tidak kompromi dengan apapun juga. 


\section{Pelayanan Yang Memuliakan Tuhan}

Bagaimana caranya dapat memuliakan Tuhan harus menjadi perenungan yang paling mendasar bagi setiap hamba Tuhan. Dan bagaimana sebenarnya memuliakan Allah itu dapat ditempuh. agar setiap hamba Tuhan dapat menyatakakannya dengan benar, tepat dan berkenan. Pelayanan yang memuliakan Tuhan tidak dapat dipisahkan dari bagaimana hamba Tuhan tersebut membangun hubungan pribadi dengan Tuhan. Hubungan pribadi dengan Tuhan akan membuat pemahaman akan Tuhan dan dirinya menjadi semakin jelas. Sebagai contoh Simon Petrus. Dalam pengalamannya sendiri dengan Yesus menyadarkan siapa dirinya dan siapa Yesus yang sebenarnya (Lukas 5:5-8). Setiap hamba Tuhan tidak dapat memuliakan Allah dalam pelayanannya jika tidak hidup bergaul dengan Allah. Dalam pengembangan diri mengenal Tuhan, hamba Tuhan terus melakukan kehendak Tuhan dengan tekun dan setia. Maka dalam proses pengambiannya melayani Tuhan akan banyak pengalaman-pengalaman spiritual bersama dengan Tuhan. Dengan demikian, akan dapat membedakan mana pelayanan tidak ada kejelasan, kehendak dirinya atau orang lain, bahkan yang dikehendaki Tuhan.

Disinilah dapat diperolah pengertian yang benar dan tepat tentang seperti apa yang sejatinya memuliakan Tuhan. Melayani Tuhan bukan berarti orang yang memperkatakan katakata pengagungan dan atau meninggikan nama Tuhan, tetapi perbuatan yang nyata dalam disetiap langkah dalam hidup. Perilakunya mencerminkan bahwa dirinya sebagai pelaku Firman Tuhan yang bersumber pada kasih akan Allah. Hamba Tuhan yang sejati pasti akan menghasilkan buah-buah yang memuliakan Tuhan. Tuhan yang memanggil dan yang menetapkan agar setiap orang percaya dan hamba Tuhan menghasilkan buah dan buahnya itu tetap (Yohanes 15:16). Buah yang dihasilkan menyangkut tentang: 


\section{Buah Pertobatan}

Menjadi pengikut Kristus dan melayani Tuhan sudah seharusnya memiliki pertobatan yang sejati. Sebagaimana Rasul Paulus menulis surat kepada jemaat di Korintus, dalam 2 Korintus 5:17 bahwa: "Barang siapa didalam Kristus adalah ciptaan baru. Yang lama berlalu, yang baru sudah terbit." Artinya, setiap orang percaya apalagi hamba Tuhan harus mengalami perubahan hidup dan menunjukkan pertobatan yang sejati.

Kata metanoia dalam Yunani “ $\mu \varepsilon \tau \alpha \dot{\alpha} v o \imath \alpha ”$ yang secara harafiah berarti "perubahan pikiran”. 8 Hal ini menandai betapa pentingnya perubahan kesadaran dan pemahaman pertobatan. Bahwa dosa adalah pelanggaran terhadap kehendak Tuhan. Pertobatan adalah penyesalan terhadap perbuatan dosa dan tindakan-tindakan nyata sebagai wujud dari keputusan pertobatan sebagai buah-buah dari pertobatan. Dengan kata lain, buah pertobatan menjadi bukti dari kualitas keimanan dan tindakan-tindakan menjadi bukti kesungguhan pertobatan. Buah pertobatan tersebut merupakan kesaksian hidup bagi semua orang.

\section{Buah Roh}

Selanjutnya buah yang harus dihasilkan bagi seorang hamba Tuhan adalah buah Roh sebagaimana tertulis dalam Galatia 5:22-23. Buah Roh merupakan kelanjutaan dari buah pertobatan. Setelah melalui buah pertobatan bertumbuh dan menghasilkan buah Roh Kudus yang mempunyai sembilan karakter. Kesembilan karakter tersebut berhubungan dengan Tuhan dan sesama. Adapun karakter dari buah tersebut adalah: Kasih, Sukacita, Damai Sejahtera, Kesabaran, Kemurahan, Kebaikan, Kesetiaan, Kelemah-lembutan dan Penguasaan diri. Ke Sembilan karakter tersebut kemudian dapat digolongkan menjadi 3 (tiga) kelompok, yaitu: pertama, kasih, sukacita, damai sejahtera merupakan tiga karakter buah Roh yang pertama yang

\footnotetext{
${ }^{8}$ https://id.wikipedia.org/wiki/Metanoia_(teologi), diakses tanggal 9 Desember 2019, pukul 11.25 WIB.
} 
berhubungan dengan Tuhan, yaitu: kasih, sukacita dan damai sejahtera. Kedua, kesabaran, kemurahan, kebaikan merupakan tiga karakter yang kedua berhubungan dengan sesama. Ketiga, kesetiaan, kelemah-lembutan, penguasaan diri merupakan tiga karakter yang terakhir berhubungan dengan diri sendiri.

\section{Buah Pelayanan}

Buah pelayanan merupakan peningkatan dari buah buah sebelumnya. Disini buah yang dihasilkan dapat dirasakan secara langsung oleh orang lain. Hamba Tuhan dapat berfungsi secara benar, tepat dan menjadi berkat. Buah pelayanan ini memdemontrasikan kebesaran dan kemahakuasaan Tuhan melalui pelayanan penggembalaan jemaat. Karena Tuhan menganugerahkan karunia-karunia Roh Kudus untuk melayani, sebagaimana tertulis dalam Surat Paulus yang pertama kepada jemaat Korintus dalam 1 Korintus 12. Roh Kudus menyertai orang percaya dan hamba-hamba Tuhan dalam melaksanakan tugas penggembalaan.

Adapun karunia Roh Kudus $^{9}$ yang terdapat dalam 1 Korintus 12 ada 9 karunia, yaitu: Karunia Berkata-kata dengan Hikmat, Karunia berkata-kata dengan Pengetahuan, Karunia Iman, Karunia Kesembuhan, Karunia mengadakan Mujizat, Karunia bernubuat, Karunia membedakan Roh, Karunia Berbahasa Lidah dan Karunia menafsirkan Bahasa Lidah. Meskipun demikian masih ada lagi karunia-karunia lain yang juga diberikan guna membangun jemaat Tuhan supaya bertumbuh dewasa dan mengembangkan pelayanan pekerjaan Tuhan sesuai dengan amanat agung Tuhan Yesus yang terulis dalam Matius 28:18-20. Penjelasan buah-buah yang harus dihasilkan sebagai hamba Tuhan dalam melaksanakan tugas penggembalaan jemaat tersebut diatas, sebagai perwujudan pengabdian hamba Tuhan kepada Tuhan sebagai tuannya.

\footnotetext{
${ }^{9}$ https://id.wikipedia.org/wiki/Karunia-karunia_Roh_Kudus\#cite_note-Udo-2, diakses tanggal 9 Desember 2019, pukul 11.28 WIB.
} 


\section{Menjaga Kemurnian Motivasi Pelayanan}

Tidak menutup kemungkinan dalam pelayanan penggembalaan jemaat dengan dipelengkapi karunia dan kuasa dari Tuhan, terdapat celah terjadinya penyimpangan dan penyalah-gunaan jabatan guna memenuhi hasrat diri dan kepentingan diri sendiri. Agar hal tersebut tidak terjadi dan kemurnian panggilan menjadi hamba Tuhan tetap terpelihara, maka sebagai hamab Tuhan sangat perlu memiliki pandangan yang benar dan jelas terhadap tugas pelayanan penggembalaan jemaat. Sehingga tetap berkomitmen untuk menjadi hamba kebenaran, yaitu mempersembahkan diri menjadi persembahan yang hidup, kudus, dan berkenan kepada Allah (Roma 12:1).

Untuk membangun motivasi pelayanan yang murni, prinsip-prinsip yang benar dan standar pelayanan yang Alkitabiah, perlu dibangun pemahaman dan pandangan tentang motivasi secara tepat. Pandangan terhadap motivasi dalam pelayanan penggembalaan sangat dibutuhkan, agar hamba Tuhan tetap menjaga diri dari motivasi yang keliru. Pandangan motivasi secara umum dapat dijelaskan sebagai berikut:

\section{Pandangan Motivasi secara Umum}

Motivasi adalah gejala psikologis dalam bentuk dorongan yang timbal balik pada diri seseorang baik sadar atau tidak sadar untuk melakukan suatu tindakan dengan tujuan tertentu. ${ }^{10}$ Seseorang saat melakukan sesuatu pekerjaan atau kegiatan apapun, pasti selalu mendapat dorongan untuk melakukan hal yang dikehendakinya. Dorongan tersebut adalah motivasi.

Motivasi $^{11}$ adalah: daya gerak yang mencakup dorongan, alasan, dan kemauan yang timbul dalam diri seseorang yang menyebabkan melakukan suatu tindakan atau berbuat sesuatu.

\footnotetext{
${ }^{10}$ Sardiman. A. M, Interaksi Dan Motivasi Belajar Mengajar, (Jakarta: CV. Rajawali), hal. 200.

${ }^{11} \mathrm{https}: / /$ pengertianahli.id/2013/09/pengertian-motivasi-menurut-para-ahli-2.html, diakses tanggal tanggal 9 Desember 2019, pukul 11.30 WIB.
} 
Pada umumnya dikenal 3 (tiga) bentuk motivasi, ${ }^{12}$ yaitu: pertama, motivasi ketakutan (Fear Motivation), yaitu motivasi yang disebabkan karena adanya rasa takut. Motivasi seperti ini terjadi adanya paksaan, tekanan atau ancaman dari berbagai pihak. Hal ini menyebabkan seseorang melakukan tindakan karena keterpaksaan, bukan karena kerelaan. Kedua, motivasi imbalan (Incentive Motivation), yaitu motivasi yang disebabkan karena adanya pemberian penghargaan atau imbalan (intensif). Imbalan ini dapat berupa pujian, prestise, atau promosi. Hal ini menyebabkan seseorang melakukan tindakan asal ada yang didapatkan, bukan karena kesadaan diri. Ketiga, motivasi sikap (Attitude Motivation), yaitu motivasi yang disebabkan karena adanya berhubungan erat dengan tujuan-tujuan yang bersifat pribadi, bukan dari luar. Bentuk ini juga disebut motivasi diri (Self Motivation).

Bob Gordon menulis tentang sifat-sifat motivasi dalam bukunya yang berjudul Master Builders, bahwa orang-orang kristen biasanya saat bertindak atau mengerjakan suatu kegiatan dikarenakan adanya sifat dari motivasi tersebut: adapun motivasi yang dimaksud ada 3 (tiga) sifat motivasi, yaitu: pertama, motivasi bersifat negatif yang terdorong karena adanya paksaan, kejengkelan, iri hati, kecemburuan, sakit hati, rasa takut, rasa besalah. Kedua, motivasi bersifat netral, karena adanya rasa bahagia, rasa senang, terhormat, tersanjung. Ketiga, motivasi bersifat positif dikarenakan adanya kedewasaan, penghormatan, kebenaran, rasa takut akan Allah,

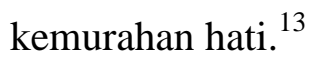

Motivasi Yang Sejati

Motivasi yang harus dimiliki oleh setiap hamba Tuhan adalah motivasi yang sejati. Adapun motivasi sejati bersumber dari Tuhan dan dilakukan dengan benar. Motivasi yang seperti

\footnotetext{
12 https://kamriantiramli.wordpress.com/2011/05/27/macam-macam-motivasi/, diakses tanggal 9 Desember 2019, pukul 11.31 WIB.

${ }^{13}$ http://yoel-setiawan.blogspot.com/2012/07/motivasi-pelayan.html, diakses tanggal tanggal 9 Desember 2019, pukul 11.33 WIB.
} 
ini ada 5 (lima) macam, yaitu: pertama, motivasi ketaatan, yaitu ketaatan yang lahir dari kesadaran akan pentingnya melakukan kehendak Tuhan. Motivasi ini merupakan perwujudan dari sifat ketundukan atau penghambaan diri kepada Tuhan yang dikerjakannya dengan sepenuh hati, jiwa dan kekuatan (Matius 22:37-39). Kedua, motivasi kasih, yaitu perwujudan dari kecintaannya kepada jiwa-jiwa yang harus diselamatkan. Motivasi ini merupakan perwujudan dari sifat pribadi Allah yang terjelma dalam hidup (Lukas 19: 1-10).

Ketiga, motivasi keteladanan, yaitu perilaku hidup yang bersumber dari keteladan Yesus Kristus. Motivasi ini merupakan perwujudan dari penerapan gaya hidup kerajaan Allah, hidup seturut dengan ajaran Yesus Kristus (Markus 10:45). Keempat, motivasi regeneratif, yaitu memandang kekristenan di masa yang akan datang. Motivasi ini merupakan kepedulian terhadap pekerjaan Tuhan dan masa depan generasi gereja dan umat Tuhan. Bagiamana dapat menghasilkan keturunan ilahi dan memberi warisan iman (Maliakhi 2:15; 2 Timotius 1:5). Kelima, motivasi eskhatologis, yaitu merupakan tindakan pencegahan terhadap perubahan zaman yang dapat merusak generasi. Motivasi ini merupakan perwujudan dari tangap dan sigap terhadap kelangsungan kekristenan dari bahaya pengaruh zaman yang semakin rusak dan jahat (2 Timotius 3:1-5).

\section{Menjaga Kemurnian Motivasi}

Menjaga kemurnian pelayanan penggembalaan selalu dilakukan secara terus menerus dan konsisten, agar sebagai hamba Tuhan tetap memiliki kesetiaan dan ketulusan dalam mengemban tugas mulia. Ada empat pokok utama yang dapat dijadikan alat ukur atau instrumen dalam menjaga kemurnian, yaitu: pertama, dipilih sebagai Pelayan atau Hamba Tuhan, yaitu: pilihan sebagai hamba Tuhan memiliki dasar yang benar. Bukan karena kemampuan intelektual, kompetensi, kekayaan. Panggilan ini merupakan keputusan diri dalam kesadaran dan keiklasan 
diri untuk mengabdi pada Tuhan. Kedua, posisi sebagai Pelayan atau Hamba Tuhan, yaitu: sebagai hamba Tuhan menempatkan diri sebagai doulos atau tidak mempunyai hak apapun untuk menuntut balasan atau penghargaan.

Ketiga, proses sebagai Pelayan atau Hamba Tuhan, yaitu: sebagai hamba Tuhan dalam menjalankan tugas dan mencapai keberhasilan tidak mengunakan cara-cara duniawi, berkompromi dengan sistem dunia dan menghalalkan segala cara supaya berhasil. Tetapi mengikuti prinsip-prinsip Alkitab dengan memikul salib, menyangkal diri mengikuti jejak Tuhan. Keempat, tujuan sebagai Pelayan atau Hamba Tuhan, yaitu: sebagai hamba Tuhan rela mengorbankan kepentingan diri sendiri demi menggenapi kehendak Tuhan dan menyelamatkan jiwa-jiwa bagi kemuliaan Tuhan.

\section{Panggilan Hamba Tuhan}

\section{Panggilan Hamba Tuhan}

Panggilan sebagai hamba Tuhan yang diterima oleh seseorang untuk menjadi gembala sidang adalah panggilan yang unik. Keunikannya bukan berdasar dari jabatan tetapi dari fungsinya yang dapat menerima siapapun tanpa membedakan latar belakangnya. Bahkan seorang hamba Tuhan dipanggil menjadi gembala sidang untuk menggembalakan jemaat dituntut melakukan tugas dan bertanggung jawab sepenuhnya. Pada umumnya antara tanggung jawab dan penghargaan tidak sebanding. Kenyataan ini sangat berbeda dengan pandangan sekuler. Hal ini suatu perkara yang tidak mudah untuk difahami, dimengerti dan dijalani dalam kehidupan.

Thomas C. Oden memberikan pandangan tentang cara mengetahui bagaimana memahami panggilan menjadi gembala sidang. Adapun cara tersebut ada 2 (dua) yaitu: pertama, inward call. Adalah panggilan tersebut merupakan sikap merespon terhadap panggilan Tuhan didasarkan 
dari kualitas panggilan itu sendiri. Jika panggilan itu hanya dialami beberapa kali saja, sebaiknya untuk diuji dulu, jangan sampai terburu-buru. ${ }^{14}$ Kedua, Outward call adalah panggilan yang sangat pribadi karena berkaitan erat dengan suasana hati dan batinnya. Meskipun demikian bukan berarti salah karena Tuhan bisa saja juga berbicara kepada seseorang dalam batinnya yang paling dalam. ${ }^{15}$

Berdasarkan penjelasan diatas, panggilan outward call merupakan peneguhan yang didapatkan dari komunitas orang percaya. ${ }^{16}$ Panggilan yang demikian dapat diuji melalui 3 (tiga) cara, yaitu: pertama, apakah dirinya memiliki bakat untuk melayani. Kedua, seberapa dirinya mempunyai kepekaan terhadap kebutuhan hidup orang lain. Ketiga, sejauh mana kompetensi diri dalam berelasi dan berinteraksi dengan orang lain. ${ }^{17}$

Berdasarkan keterangan diatas dapat disimpulkan, bahwa panggilan Tuhan menjadi hamba Tuhan untuk menggembalakan jemaat hal yang tidak mudah. Butuh kepekaan, peneguhan dari orang lain dan tanda-tanda yang dapat menyakinkan dirinya dipanggil Tuhan.

\section{Arti Panggilan Hamba Tuhan}

Dipanggil sebagai hamba Tuhan menjadi seorang gembala sidang merupakan panggilan yang sangat berat. Gembala Sidang melakukan pekerjaan yang sebelumnya dilakukan ketika dipanggilan Tuhan. Bahkan pekerjaan tersebut mengandung resiko yang besar, karena harus mengorbankan segala sesuatunya untuk dicurahkan dalam pelaksanaan tugas panggilan Tuhan atas dirinya. ${ }^{18}$ Sebagai contoh dalam perjanjian lama adalah Daud (1 Samuel 17:34-36) dan dalam Perjanjian Baru adalah Rasul Paulus (2 Korintus 4:7-11).

\footnotetext{
${ }^{14}$ Thomas C. Oden, Pastoral Theology, (New York: Harper San Fransisco), 1983, hal. 18.

${ }^{15}$ Robert C. Anderson, The Effective Pastor, (Chicago: Moody Press), 1993, hal. 20.

${ }^{16}$ Thomas C. Oden, Pastoral Theology, (New York: Harper San Fransisco), 1983, hal. 20.

${ }^{17}$ Robert C. Anderson, The Effective Pastor, (Chicago: Moody Press), 1993, hal. 20-21.

${ }^{18}$ Oswald Sanders, Kepemimpinan Rohani, terjemahan Chris J. Samuel, (Bandung: Kalam Hidup), 1979 ,
} hal. 63 . 
Seorang Hamba Tuhan dituntut menjadi teladan ditengah-tengah jemaat dan masyarakat pada umumnya. ${ }^{19}$ Sekaligus bertanggung jawab kepada Tuhan. Sikap hidupnya mencerminkan hidup Kristus yang hidup didalam hidupnya yang dapat memberikan inspirasi dan pengaruh terhadap orang lain. Kesadaran panggilan Tuhan menjadi hamba Tuhan dalam pelayanan penggembalaan jemaat menjadi bagian penting disepanjang perjalanan hidupnya. Tetap terus belajar dan membangun hubungan pribadi dengan Tuhan Sang pemilik ladang pelayanan.

\section{Status Dalam Panggilan}

Sebagai hamba Tuhan yang melayani penggembalaan jemaat statusnya tidak ditentukan oleh jabatan, pangkat atau pendidikan, tetapi lebih pada dedikasi, intregritas dan pengabdiannya kepada Tuhan, kepada umat Tuhan dan masyarakat pada umumnya. Sehingga kehadirannya dapat diterima sepenuhnya. Hal ini sangat berbeda atau berbanding terbalik dengan standar yang dipakai oleh dunia sekuler.

Status yang diperoleh hamba Tuhan dalam panggilan sebagai gembala sidang diperoleh dari kesetiaan dan ketekunannya mengabdi dan melayani. Diteguhkan dengan melakukan tugas dan janggung jawabnya dengan sepenuh hati. Diperkuat dengan antusiasme dan semangat berjuang dengan tanpa pamrih. Sehingga status bukan yang utama tetapi fungsi yang maksimal dan buah pelayanannya.

\section{Profesional Dalam Panggilan}

Sebagai hamba Tuhan dalam menjalankan tugasnya dituntut profesional. Profesionalitas ini akan mendatangkan perubahan, pertumbuhan dan kedewasaan jemaat yang dipimpin. Hal ini bukan berarti meninggalkan makna pelayanan, tetapi justru menjadikan pelayanan tersebut suatu

\footnotetext{
${ }^{19}$ Peter Wongso, Theologia Penggembalaan, (Malang: Sekolah Alkitab Asia Tenggara), 1996.
} 
pekerjaan yang menghasilkan pertumbuhan dan peningkatan tentang kualitas maupun kuantitas jemaat yang sesuai dengan kehendak Tuhan. Profesional dalam menjalankan pelayanan penggembalaan jemaat akan membawa pada sasaran dan tujuan yang jelas tepat dan pasti. Itulah sebabnya seorang hamba Tuhan perlu memperlengkapi diri dengan pengetahuan dan pemahaman yang menyangkut tentang diri sendiri, penggembalaan, pengelolaan dan jemaat yang Tuhan percayakan.

Peter Wongso ${ }^{20}$ dalam bukunya yang berjudul Theologia Penggembalaan memberi pernyataan, bahwa seorang gembala sidang harus memiliki pengetahuan tentang dirinya sendiri, sebelum berbicara tentang talenta, pendidikan dan pelayanan. Mengenali kepribadiannya sangat menentukan keberhasilan dalam penggembalaan. ${ }^{21}$ Dengan pengenalan diri sendiri akan dapat membawa diri dengan baik, benar dan bertindak dengan bijaksana.

Selanjutnya, seorang hamba Tuhan dalam menggembalakan jemaat memiliki pengenalan akan kebutuhan jemaat. Supaya dalam proses penggembalaan jemaat dapat menyediakan kebutuhan yang sesungguhnya, bukan sesuatu yang bersifat retorika. Disetiap tempat dan daerah selalu ada kebutuhan yang berbeda satu dengan yang lainnya. Kebutuhan yang dimaksudkan disini bukan berarti berupa materi atau perkara kesenangan, tetapi kebutuhan yang memungkinkan adanya perkembangan dan pertumbuhan ke arah kepenuhan Kristus. Disinilah dibutuhkan kepekaan dan kecerdasan dalam menyingkapi apa yang sesungguhnya dibutuhkan jemaat, untuk bertumbuh, dewasa dan berbuah.

Seorang hamba Tuhan juga harus mengerti dengan benar tentang tugas dan tanggung jawab yang utama serta peranannya dalam penggembalaan jemaat, yaitu: pertama, dalam sikap. Melakukan pelayanan tidak dengan terpaksa tetapi dengan sukarela sesuai dengan kehendak

\footnotetext{
${ }^{20} \mathrm{Ibid}$.

${ }^{21}$ Ibid.
} 
Allah. Tidak mencari keuntungan bagi dirinya sendiri tetapi pengabdian diri dengan kemurnian hati. Tidak berdiri sebagai seorang yang berkuasa, tetapi memberi keteladanan Kristus melalui hidupnya kepada jemaat yang Tuhan percayakan (1 Petrus 5:2-3). Kedua, dalam perbuatan. Dapat menunjukkan kepedulian terhadap jemaat dengan segala pergumulannya. Memberikan perlindungan dari ajaran-ajaran sesat yang dapat membelokkan arah jemaat kepada penyesatan. Menyediakan diri memberi nasehat, nenuntun, menghibur dan memberikan kekuatan kepada jemaat dalam menghadapi kesukaran dan perjuangan hidup. Dan secara kontinu memberi pimpinan untuk mengarahkan langkah hidup dalam kebenaran dan sesuai dengan kehendak Tuhan.

\section{Urutan Prioritas Panggilan.}

Prioritas artinya mendahulukan sesuatu yang kita anggap lebih penting dibandingkan dengan hal-hal yang lain. Dasar utama dalam menentukan prioritas hidup adalah Tuhan. Alkitab menjelaskan bahwa mengasihi Tuhan harus menjadi prioritas utama dan yang pertama (Matius 22:37-38; Lukas 10:38-42). ${ }^{22}$ Kegagalan yang terjadi dalam pelayanan penggembalaan bukan karena kurang mampu, kurang berjuang dan kurang sungguh-sungguh dalam melayani jemaat Tuhan, tetapi karena jarang disadari, dipahami dan diresponi dengan baik dalam menempatkan prioritas dalam melaksanakan panggilan Tuhan. Kesalahan fatal terjadi karena terjadinya urutan prioritas yang tidak tepat dan yang seharusnya. Prioritas yang harus ditempatkan secara benar adalah:

Pertama, Tuhan menjadi urutan pertama karena Sang Pencipta yang memberi hidup dan kepercayaan untuk ambil bagian dalam pekerjaan-NYA. Itulah sebabnya hamba Tuhan harus dapat menggunakan waktu bersama Tuhan dalam doa; dalam mempersiapkan tugas pelayanan;

\footnotetext{
${ }^{22}$ http://nikennababan.blogspot.com/2014/02/12.html, diakses tanggal 9 Desember 2019, pukul 11.39 WIB.
} 
dalam kesetiaan dan ketaatan pada perintah Tuhan dan dalam menjaga intregitas dan kekudusan. Tuhan menjadi yang utama dari segala sesuatu.

Kedua, Keluarga menjadi urutan yang kedua karena hamba Tuhan harus dapat mengepalai keluarga yang dipercayakan Tuhan sebelum terhadap jemaat dan orang lain. Keluarga adalah jiwa-jiwa pertama yang dipercayakan Tuhan untuk digembalakan. Jika sampai terjadi kegagalan, sangat memungkinkan tidak berhasil pula dalam penggembalaan jemaat. Hamba Tuhan harus komitmen dengan pernikahan dan keluarga, menyediakan diri dan waktu untuk bercengkeraman dalam hubungannya dengan Tuhan dan kebersamaan menjalani kehidupan.

Ketiga, Pelayanan gereja menjadi urutan ketiga karena panggilan Tuhan untuk melayani Tuhan dalam penggembalaan jemaat. Hamba Tuhan secara bijak dalam menempatkan diri melaksanakan tugas berdampingan dengan tanggung jawab terhadap keluarga. Sehingga tanpa mengubah posisi urutan, pelaksanaan tugas dan tanggung jawab dapat dilaksanakan dengan baik dan benar.

Keempat, Orang lain atau kegiatan lain menjadi urutan ke empat karena sebagai makhluk sosial dan amanat Agung memerintahkan demikain. Implementasi dari pelayanan terhadap Tuhan, keluarga dan gereja diwujudkan ditengah-tengah kehidupan didunia ini.

\section{Tugas Penggembalaan Jemaat}

Gembala sidang sebagai hamba Tuhan adalah bagian yang tidak dapat dipisahkan dengan tugas-tugasnya. Maka gembala sidang selalu berhubungan dengan pelaksanaan kegiatan penggembalan jemaat. Adapun tugas utama gembala sidang ada 5 (lima) bagian secara terpisah tetapi saling berkaitan antara satu dengan yang lainnya. Tugas tersebut adalah: 
Gembala Sidang Sebagai Pemberita Firman.

Gembala sidang sebagai pembawa berita Firman untuk menjelaskan kebenaran apa yang terkandung didalamnya, sehingga orang yang menerimanya dapat memahami, menerima dan menjadikannya sebagai pedoman hidup (2 Timotius 4:2). Memberitakan Firman bukan sesuatu yang orang pernah diputuskan untuk melakukan itu. Apa yang terjadi agaknya adalah bahwa ia menjadi sadar akan "panggilan”.

Secara umum panggilan mulai dalam bentuk kesadaran dalam roh seseorang, sesuatu yang mengganggu dalam roh, kemudian pikiranmu diarahkan kepada pertanyaan-pertanyaan tentang pemberitaan firman. Tujuan memberitakan Firman Tuhan merupakan amanat agung yang tertulis dalam Matius 28:18-20 yaitu, "Karena itu pergilah, jadikanlah semua bangsa murid-Ku dan baptislah mereka dalam nama Bapa, dan Anak dan ROH KUDUS, dan ajarlah mereka melakukan segala sesuatu yang telah Kuperintahkan kepadamu. Dan ketahuilah, Aku menyertai kamu senantiasa sampai pada akhir zaman.,"23

Jadi, tujuan dari pemberitaan tersebut adalah: pertama, untuk memimpin orang-orang yang menerimanya, menerima dan mempercayai serta mengasihi Firman Tuhan (Yohanes 5:3940). Kedua, untuk memimpin orang-orang untuk mengenal dan memahami kebenaran-kebenaran serta prinsip-prinsip Firman Tuhan (2 Timotius 4:2). Ketiga, untuk memimpin orang-orang yang menerimanya hidup sesuai dengan kehendak Tuhan. Berkaitan dengan kemurnian sebagai hamba Tuhan, gembala sidang memberitakan Firman bukan untuk mempromosikan diri, bukan membangun opini, bukan mengajarkan filsafat, bukan untuk mendapatkan keuntungan pribadi dan memenuhkan hasrat pribadi.

\footnotetext{
${ }^{23}$ http://forumkristen.com/index.php?topic=51990.0, diakses tanggal 9 Desember 2019, pukul 12.05 WIB.
} 
Pemberitaan firman ini harus dipahami sebagai hak istimewa yang kudus dan mulia. Gembala sidang tidak mengalihkan tanggung jawab misi penyelamatan jiwa-jiwa kepada jemaat. Meskipun tugas penggembalaan sudah cukup berat, tetapi secara pribadi tetap punya tanggung jawab memberitakan kesaksian kebenaran Injil kepada semua orang. Mengabarkan Injil kabar baik merupakan keharusan bagi setiap orang Kristen, terlebih sebagai hamba Tuhan.

\section{Gembala Sidang Sebagai Pengajar Firman}

Artinya Gembala sidang sebagai pengajar firman menyampaikan pengajaran kepada umat Tuhan guna pembangunan Tubuh Kristus melalui khotbah, pendalama Alkitab dan komunitaskomunitas Kristen. Tujuan memberikan pengajaran tersebut meliputi: pertama, pendidikan. Yaitu mengajar umat di dalam ajaran yang sehat dan prinsip-prinsip Firman Tuhan (Matius 28:20; Titus 2:1). Kedua, memperlengkapi. Membina dan memperlengkapi umat Tuhan hidup benar benar dan sesuai dengan kehendaki Tuhan, sehingga hidup bagi Kristus dan melayani Tuhan ditengah-tengah umat Tuhan (2 Timotius 3:16-17; Efesus 4:11-16). Ketiga, membangun iman. Menuntun dan membimbing umat Tuhan bertumbuh dalam iman menuju kedewasaan dalam Kristus (Kolose 1:28-29). Keempat, memberi dorongan. Membangkitkan semangat umat Tuhan dan menyakinkan mereka untuk percaya pada janji-janji Tuhan dan dan memiliki pengharapan yang pasti ( Roma 15:1-4). Kelima, memberikan perlindungan dari pengajaran sesat dan guru-guru palsu (Kisah Para Rasul 20:27-31; Titus 1:9).

Dalam kaitannya dengan kemurnian sebagai hamba Tuhan, Gembala sidang secara jujur, berterus terang menyatakan kebenaran Firman Tuhan kepada jemaat tanpa harus ditutup-tutupi oleh karena hubungan, tujuan tertentu dan ada tujuan-tujuan tertentu. Gembala harus menyampaikan Firman Tuhan dengan gamblang dan benar. 


\section{Gembala Sebagai Pelayan Jemaat}

Artinya gembala sidang sebagai pelayan dapat menempatkan diri seorang hamba bukan tuan atau penguasa (1 Petrus 5:1-4). "Pelayan" berarti hamba yang melayani orang lain, memenuhi kebutuhan orang lain dan melakukan pelayanan bermanfaat bagi orang lain. Gembala jemaat tidak lain adalah seorang hamba. Ia adalah seorang hamba dalam hubungannya dengan Allah (Matius 24:45). Dalam posisinya sebagai seorang gembala jemaat, ia berkewajiban untuk melayani jemaat dan bertanggung jawab terhadap Allah atas kehidupan jemaat yang digembalakannya. $^{24}$

Berhubungan dengan fungsinya, gembala sidang meliputi: pertama, memperdulikan kebutuhan-kebutuhan fisik, mental emosi, dan rohani dari umat gembalaannya. Kedua, membangun relasi dengan umat secara pribadi. Ketiga, memelihara, menghibur, dan memberi dorongan kepada umat. Keempat, melakukan pelayanan-pelayanan untuk kepentingan umat yang digembalakan.

Seorang gembala sebagai pelayan, memikul tanggungjawab pelayanan kasih, perhatian, dan kepedulian terhadap umat gembalaannya baik secara bersama, maupun secara orang per orang. Dalam kaitannya dengan kemurnian sebagai hamba Tuhan, gembala sidang harus memiliki kerelaan dan kerendahan hati mengabdi kepada Tuhan tanpa pamrih, serta rela berkorban demi terjadinya tranformasi seutuhnya gereja Tuhan. Secara effektif gembala mengenali jemaat secara pribadi; Memenuhi kebutuhan-kebutuhan yang riil dari umat gembalaannya sebagai gembala mereka; Menyadari posisinya sebagai suatu hak Istimewa yang diberikan Allah kepadanya.

$24 \quad$ https://media.neliti.com/media/publications/105119-peran-gembala-jemaat-terhadap-pengembang7f30626b.pdf, diakses tgl 9 desember 2019, pukul 12.12 WIB. 


\section{Gembala Sebagai Konselor}

Artinya gembala sidang sebagai konselor memberi pelayanan konseling kepada jemaat dan memperlangkapi jemaat dengan pemahaman-pemahaman dan prinsip-prinsip hidup yang sesuai dengan Firman Tuhan (Mazmur 23:1-6). Kata konseling (counseling) berasal dari kata counsel dari bahasa latin counselium artinya "bersama" atau "bicara bersama". 25 Berbicara bersama-sama adalah pembicaraan konselor (counselor) dengan seorang atau beberapa klien (counselor). Counselium berarti people coming together to gain an understanding of problem that beset them were evident. ${ }^{26}$

Kata konseling dapat disimpulkan sebagai suatu kegiatan dimana seseorang yang menguatkan, menghibur yang dimintakan nasehat dan merunding dengan seseorang. Peranan gembala dalam pelayanan konseling sangat besar. Sebab bukan hanya sekedar berkotbah atau mengejar, tetapi mendampingi jemaat dalam menghadapi dan menyelesaikan masalah-maslah hidup yang dihadapi secara benar dan bijaksana. Pelayanan konseling harus berlandaskan pada prinsip-prinsip dan kode etik, supaya dapat menjaga kerahasiaan dan memberi kenyamanan privasi jemaat. Itulah sebabnya gembala dalam peranananya sebagai konselor harus memiliki kredibilitas, integritas dan skill konseling, agar dapat memberi solusi yang alkitabiah, tepat dan sesuai kebutuhan.

Agar peranannya dapat efektif, maka gembala sidang harus: pertama, membangun vitalitas dari hidup bergaul dengan Allah. Kedua, mempertajam kemampuannya mengenal Alkitab dan mengaplikasikannya. Ketiga, meningkatkan kedewasaan rohaninya serta ketajaman yang dimilikinya. Keempat, memperkuat kesiapan diri untuk mengatakan kebenaran dalam kasih. Kelima, mempertebal kepercayaannya pada Firman Tuhan dan kuasa Roh Kudus dalam

\footnotetext{
${ }^{25}$ http://digilib.uinsby.ac.id/5582/10/Bab\%202.pdf, diakses tgl 9 desember 2019, pukul 12.14 WIB.

${ }_{26}$ http://kumpulan-materi.blogspot.com/2012/04/pengertian-konseling.html, diakses tanggal 9 Desember 2019, pukul 12.19 WIB.
} 
menyingkapi dan menghadapi tugas pelayanannya. Keenam, membangkitkan gairah umat Tuhan dalam membimbing, nasihat dan memeberi petunjuk. Berkaitaan dengan kemurnian sebagai hamba Tuhan, menjaga hubungan yang sehat dan menerapkan norma dan etika berlelasi dengan orang lain dan menerapkannya secara profesional.

\section{Gembala Sebagai Pemimpin}

Artinya sebagai gembala sidang dalam kepemimpinannya adalah bagian dari kepemimpinan Kristen. Pemimpin gereja adalah pemimpin rohani. Sebagai pemimpin rohani, ia memiliki tanggung jawab besar serta penting dan berat untuk menjalankan upaya memimpinnya. Sebagai hamba Tuhan, pemimpin sangat bertanggung-jawab meneguhkan sikap terhadap diri sendiri serta rumah tangganya, dan sikap terhadap pelayanannya, sehingga ia terbukti layak untuk memimpin umat Allah. Gembala sebagai pemimpin, salah satu peran dan tanggung jawab yang sangat menentukan pertumbuhan gereja adalah pemimpin. ${ }^{27}$

Kepemimpinan adalah proses mempengaruhi atau memberikan contoh oleh pemimpin kepada pengikutnya dalam upaya mencapai tujuan. Kepemimpinan adalah proses mempengaruhi atau memberikan contoh oleh pemimpin kepada pengikutnya dalam upaya mencapai tujuan tertentu organisasi. ${ }^{28}$ Gembala sidang seorang pemimpin gereja harus mencontoh teladan Gembala Agung yaitu Tuhan Yesus Kristus dengan "hidup seperti Dia” (Yohanes 10:11; 1 Yohanes 2:6).

Adapun tugasnya berkaitan dengan kepemimpinannya, gembala sidang harus: pertama, mendemonstrasikan iman, pengharapan, dan kasih sehingga menjadi teladan yang baik bagi

${ }^{27}$ file:///C:/Users/ASUS/Downloads/100-1157-2-PB.pdf, diakses tanggal 9 Desember 2019, pukul 12.26 WIB.

28 https://www.scribd.com/document/350964494/Kepemimpinan-Adalah-Proses-Memengaruhi-AtauMemberi-Contoh-Oleh-Pemimpin-Kepada-Pengikutnya-Dalam-Upaya-Mencapai-Tujuan-Organisasi, dikases tanggal 9 Desember 2019, pukul 12.32 WIB. 
jemaat gereja. Kedua, memelihara, melindungi dan menjaga kehidupan spiritual anggota jemaat gereja yang dipimpinnya. Ketiga, melakukan pengawasan, baik terhadap kehidupan gereja serta jemaatnya. Keempat, memimpin dengan sukarela, penuh kasih dan sukacita, serta tidak mencari keuntungan sendiri. Sebab pemimpin gereja adalah representasi Kristus bagi jemaatnya (1 Petrus 5:1-5; Ibrani 13:17). ${ }^{29}$

\section{Penutup}

Pentingnya pemahaman pengertian tentang hamba Tuhan dalam pelayanan penggembalaan jemaat perlu dibangun sejak dari awal menerima panggilan Tuhan. Pemahaman tersebut meliputi pelayanan yang alkitabiah, bagaimana memiliki kemurnian dan kenyakinan tentang panggilan Tuhan terhdap dirinya. sehingga dalam pelaksanaan tugas penggembalaan terhindar dari penyalahgunaan wewenang atau terjadinya penyimpangan-penyimpangan yang berakibat fatal atas dirinya dan pelayanan yang diembannya. Akan tetapi dapat melaksanakan tugas dengan baik, terarah, dan maksimal sesuai dengan kehendak Tuhan, menjadi berkat bagi jemaat Tuhan dan menghasilkan buah yang menyenangkan hati Tuhan Hal ini akan memberi arah yang jelas dalam menjalakan Tugas dan konsisten terhadap panggilan sebagai hamba Tuhan menggembalakan jemaat Tuhan.

${ }^{29}$ https://tuhanyesus.org/tugas-seorang-pemimpin-gereja, diakses tanggal 9 Desember 2019, pukul 12.35 WIB. 


\section{DAFTAR PUSTAKA}

Anderson, Robert C. The Effective Pastor, Chicago: Moody Press, 1993.

M, Sardiman A. Interaksi Dan Motivasi Belajar Mengajar, Jakarta: CV. Rajawali,

Oden, Thomas C. Pastoral Theology, New York: Harper San Fransisco, 1983.

Peter Wongso, Theologia Penggembalaan, Malang: Sekolah Alkitab Asia Tenggara, 1996.

Sanders, Oswald. Kepemimpinan Rohani, terjemahan Chris J. Samuel, Bandung: Kalam Hidup, 1979.

Subagyo, Andreas B. Pengantar Riset Kuantitatif Dan Kualitatif, Bandung: Yayasan Kalam Hidup, 2004.

Halaman Situs Daring

http://kepemimpinanmelayani.blogspot.com/2016/12/materi-kuliah-kepemimpinan-kristen.html

https://en.m.wikipedia.org/wiki/The_Thanatos_Syndrome

https://alkitab.mobi/renungan/sh/2015/03/27/

https://id.wikipedia.org/wiki/Diaken

http://pandiealfons.blogspot.co.id/melayani-bukan-dilayani-suatu-analisa.html

https://id.wikipedia.org/wiki/Metanoia_(teologi)

https://id.wikipedia.org/wiki/Karunia-karunia_Roh_Kudus\#cite_note-Udo-2

https://pengertianahli.id/2013/09/pengertian-motivasi-menurut-para-ahli-2.html

https://kamriantiramli.wordpress.com/2011/05/27/macam-macam-motivasi/

http://yoel-setiawan.blogspot.com/2012/07/motivasi-pelayan.html

http://nikennababan.blogspot.com/2014/02/12.html

http://forumkristen.com/index.php?topic $=51990.0$ 
https://media.neliti.com/media/publications/105119-peran-gembala-jemaat-terhadappengembang-7f30626b.pdf

http://digilib.uinsby.ac.id/5582/10/Bab\%202.pdf

http://kumpulan-materi.blogspot.com/2012/04/pengertian-konseling.html

file:///C:/Users/ASUS/Downloads/100-1157-2-PB.pdf

https://www.scribd.com/document/350964494/Kepemimpinan-Adalah-Proses-Memengaruhi-

Atau-Memberi-Contoh-Oleh-Pemimpin-Kepada-Pengikutnya-Dalam-Upaya-Mencapai$\underline{\text { Tujuan-Organisasi }}$

https://tuhanyesus.org/tugas-seorang-pemimpin-gereja 